\section{Mange fraktur- pasienter har vært mishandlet av partneren}

\author{
Én av seks av kvinner som ble \\ henvist til ortopedisk poliklinikk \\ på grunn av fraktur rapporterte \\ at de hadde vært utsatt for vold \\ fra sin partner.
}

En studie som nylig er publisert i The Lancet omfattet nesten 3000 kvinner henvist til ortopediske poliklinikker i Canada, USA, Nederland, India og Danmark pga. fraktur (1). Én av seks rapporterte at de hadde vært utsatt for vold fra sin partner én eller flere ganger i løpet av livet, og hos $2 \%$ var vold fra partneren årsak til den aktuelle skaden. Rundt to tredeler av kvinnene mente at helsepersonell bør spørre sine pasienter om de har vært utsatt for mishandling, men bare $4 \%$ hadde fått spørsmålet.

- Flere studier har vist at partnervold er en vanlig årsak til sykdom og skader, noe denne studien også viser, sier Berit Schei, professor ved Norges teknisk-naturvitenskapelige universitet og overlege ved St. Olavs hospital. - Det er ingenting som tyder på at vi er bedre stilt i Norge.

Schei har selv forsket på partnervold. I en populasjonsbasert studie publisert i 2008 rapporterte rundt $8 \%$ av nesten 2100 kvinner at de hadde opplevd så alvorlig vold fra sin partner at de hadde fătt fysiske skader (2).

- Partnervold forblir ofte en skjult årsak, påpeker Schei. - Konkrete spørsmål om hvorvidt en skade skyldes vold, bør inngå i rutinene. Systematisk dokumentasjon av skader med vurdering av årsaksforhold kan ha stor betydning ved en eventuell rettssak.

\section{Ole Kristian Losvik}

losvik@gmail.com

St. Olavs hospital

\section{Litteratur}

1. PRAISE Investigators. Prevalence of abuse and intimate partner violence surgical evaluation (PRAISE) in orthopaedic fracture clinics: a multinational prevalence study. Lancet 2013. E-publisert 11.6

2. Nerøien Al, Schei B. Partner violence and health results from the first national study on violence against women in Norway. Scand J Public Health 2008; 36: 161-8.

\title{
Rett til ammefri
}

\section{Verdens helseorganisasjon (WHO) anbefaler at spedbarn fullammes til de er seks måneder gamle. En ny studie tyder på at det er flere som følger anbefalingen i land der ammepauser er garantert.}

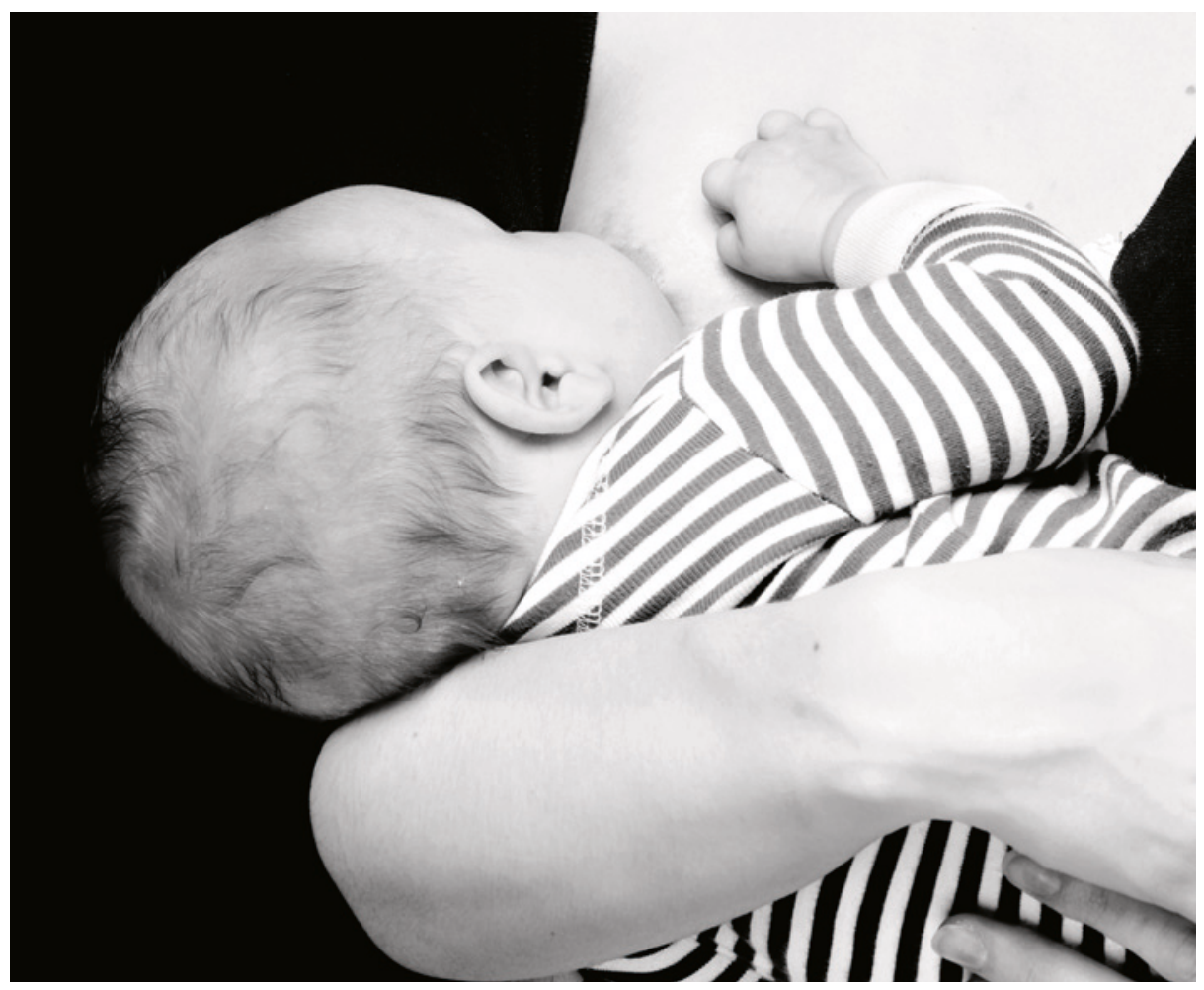

Illustrasjonsfoto Thinkstockphoto

Amming bidrar til reduksjon i risikoen for diaré, luftveissykdommer, underernæring og død hos nyfødte. WHO anbefaler at spedbarn fullammes til seks måneders alder, men det er store variasjoner landene imellom når det gjelder andelen som kun får morsmelk i denne perioden. En av grunnene til at anbefalingen ikke blir fulgt, er at mødrene skal tilbake i jobb. I en ny studie, som omfattet 182 av FNs 193 medlemsland, ble mødres rett til ammepauser sammenliknet (1). Betalte ammepauser var garantert i 130 land $(72 \%)$. I sju land ( $4 \%$ ) var pauser garantert, men ikke med lønn, og i de resterende 45 landene $(25 \%)$ var det ingen retningslinjer for ammepauser. Blant de landene der kvinnene hadde rett til betalte pauser, fantes også de som garanterte foreldrepermisjon i de første seks månedene.

Forskerne fant at $\mathrm{i}$ land med lover som garanterer betalte ammepauser inntil barnet var minst seks måneder gammelt, var det en større andel som fulgte WHOs anbefaling enn i land uten slik garanti - andelen barn som ble fullammet de første seks månedene var nærmere 9 prosentpoeng høyere, kontrollert for faktorer som bruttonasjonalprodukt, andel av befolkningen som bodde i urbane områder og andel av kvinner som kunne lese og skrive. Forfatterne understreker at det er behov for flere studier for å bekrefte denne assosiasjonen, men anbefaler likevel at man i land der man ennå ikke har vedtatt rett til ammepauser for nybakte mødre, får dette på plass.

\section{Merete Kile Holtermann}

merete.holtermann@legeforeningen.no Tidsskriftet

\section{Litteratur}

1. Heymann J, Raub A, Earle A. Breastfeeding policy: a globally comparative analysis. Bull World Health Organ 2013; $91: 398-406$ 